all over the world. Succeeding this period is the approach to sanity, orderliness and healthy competition, with explorations, new discoveries, technical developments on an unprecedented scale, leading up to the 1939 calamity. The period 1939-45 is rightly described as when "The Industry Gives its All", with petroleum 'in action' as never before. The last phase, 1946-49, "The Threshold of Freedom", reveals that struggle is still going on in the oil world as in other spheres of human activity. This jubilee number is beautifully produced and illustrated, and, as a permanent record of fifty years of British achievement in the petroleum industry and in the making of this periodical, it should find a placejin every oilman's library.

\section{New Plant Diseases}

THE life-bistory of Ramularia onobrychidis is described by $F J$. Hughes in a recent paper (Trans. Brit. Mycol Ajoc., 32, Pt. 1, $34 ; 1949)$. This fungus causestadeaf spot of sainfoin : it produces chains of ctpidia from spring to early autumn, and also makes scldrotia in winter. The latter remain viable for a confiderable period, and produce conidia from the neck cells. Pathogenicity of the fungus has been proved by inoculation with conidia; but no perithecial stage has yet been found. Another leaf spot of sainfoin, caused by Septoria orobina, has also been described by the same author (ibid., pp. 60-62). W. C. Moore mentions three new fungal plant diseases (ibid., pp. 95-99). Zythia fragarioe, which is responsible for a leaf blotch on strawberry, can also produce similar damage on Geum. A downy mildew on Alyssum saxatile was found due to Peronospora galligena. Downy mildew of the vine, Plasmopara viticola, has probably been confused with powdery mildew on the same host; but several authenticated records in England are now given. A fourth malady, black heart of potato, is non-parasitic; it may be due to unsatisfactory clamping conditions, though it is possible that the symptoms were induced by high soil temperature while the tubers were still attached to the parent plant.

\section{HE \\ New Insecticides}

A Concise report on many of the newer insecticides has been prepared by a committee of the Mushroom Growers' Assgotation, Yaxley, Peterborough (12 pp., 2s. 6 net April 1949). D.D.T., 'Gammexane', azobenzeno, hexaethyltetraphosphate and tetraethyl. py ophos thate are described in some detail, and parathion ( $E$ 605), velsicol 1068, Dynone II and pipe ine are also mentioned. Methods of application are discussed. The report is in the nature of a grower's guide, and more experimental work must be done before any overall recommendation can be made.

\section{Earthquakes During May}

ELEvEN strong earthquakes and many minor ones occurred dur. $\mathrm{g}$ May. All the major ones had their epicentres ${ }^{i}$ well-known seismic zones, and fortunately mgs were either in the sea or in uninhabited places $\mathrm{fon}$ land. No really deep-focus earthquakes we anong them, though at least three had deeper focthan is normal, namely, those on May 3 in the Kurlle Islands, and on May 8 and 30 off the coast of northern Chile. These were also three of the four strongest shocks of the month, the fourth being the earthquake on May 9, with a normal depth of focus, and epicentre near the coast of north-west Sumatra. Three local shocks are also worthy of note. The first, on May 1, was felt at Horta in the Azores; the second was in southern California and was felt at Santa Monica, Los Angeles, Blythe and Elsinore with scale 4 (Modified Mercalli scale); the third was in France in the Departments of Nièvre and Saone et Loire, being felt in the former at Château-Chinon and in the latter at Anost with scale 3-4 (Modified Mercalli scale). Readings of instrumental records have been received from the central stations of the United States Coast and Geodetic Survey and Strasbourg, and from individual observatories at Cleveland (Ohio), De Bilt (Netherlands), Durham, Edinburgh, Kew, Stuttgart and Toledo.

\section{Diploma in Animal Genetics at Edinburgh}

THE Uydversity of Edinburgh has recently instituted a fiploma in animal genetics. The course lasts one year, during which students spend about half theif time attending lectures and practical work, and dysing the remainder undertake directed research or attend other suitable courses in the University. Candidates should be honours graduates in a biological subject or in mathematics, or must otherwise satisfy the University of their fitness to enter the diploma course. It is expected that, during the coming year, Prof. Sewall Wright of Chicago will be in Edinburgh as a Fulbright visiting professor and will take part in the course.

\section{International Union of Nutritional Sciences}

IN connexion with meetings of the Committee of the Internatighal Union of Nutritional Sciences, to be held in Copenhagen during September 12-14, it has been/arranged to hold some scientific sessions and vigits to institutes of nutritional interest in the neighlourhood of Copenhagen between Monday and Friday, September 12 and 16, inclusively. It is thought that this may be of interest to a wider circle of nutritional workers, and those interested are invited to communicate with Prof. H. Dam (Biology Department, Polytechnic Institute, Østervoldgade $10 \mathrm{~L} \mathrm{11,} \mathrm{Copenhagen,} \mathrm{Denmark),} \mathrm{or} \mathrm{Dr.} \mathrm{Torben} \mathrm{K.}$ With (Rigshospitalet, Copenhagen, Denmark), who are taking charge of the local arrangements.

\section{Announcements}

THE following have been elected to Beit Fellow. ships for Scientific Research of the value of $£ 500$ per annum pach, tenable at the Imperial College of Scienco and Technology : A. R. Boothroyd, for reseprch in electrical engineering under the direction of Prof. Willis Jackson; G. E. Gadd, for research in aeronautics under the direction of Prof. A. A. Hall ; J. T. Law, for research in physical chemistry under the direction of Prof. H. V. A. Briscoe.

DR. J. R. M. InNes, formerly of the Institute of Animal Ppthology, Lniversity of Cambridge (192640), and head of the Subdivision of Pathology, Biological Laboratories, Imperial Chemical Indus. tries, Manchester $(1940-47)$, has been awarded a spocial research fellowship by the United States Public Health Services, Division of Mental Science. Dr. Innes will work at the Microbiological Institute, National Institutes of Health, Bethesda, Maryland, on demyelination encephalopathy in lambs and dogs. 